(RESEARCH ARTICLE)

\title{
Influence of feeding garlic plant either as powder or oil on reproductive performance of ewes
}

\author{
Nassar Mahmoud, El Shereef Afaf*, Abo Bakr Salah \\ Animal and Poultry Nutrition Department, Desert Research Center, Matariya, Cairo, Egypt.
}

Publication history: Received on 17 December 2017; Accepted on 28 December 2017

https://doi.org/10.30574/gscbps.2017.1.3.0064

\begin{abstract}
Garlic as feed additives has been shown to favorably effects in in vitro studies, but there are a few in vivo studies that have examined female animal responses in different physiological stages (pregnant and lactating). Therefore, the objective of this study was to evaluate the effects of garlic powder and garlic oil additives on feed intake, ruminal fermentation, blood metabolites and reproductive performance of ewes. Eighteen pregnant ewes aged 2-3 years and weighed $40.86 \mathrm{~kg}$ body weight at late gestation were selected and randomly distributed into three similar groups (6 in each). The first group (G1) fed on concentrate feed mixture to cover $60 \%$ of their energy maintenance requirements + clover hay to cover the remain percentage (control ration). The second group (G2) fed control ration + garlic powder as $2 \%$ of dry matter intake. While the third group (G3) fed control ration $+2 \mathrm{ml} / \mathrm{head} /$ day of garlic oil. The trial lasted for 4 months (one month at late gestation followed by three months at lactation period). Data revealed the positive effect of garlic powder and their oil on rumen ammonia concentration and Protozoa number. While, ruminal pH levels, volatile fatty acids concentrations, dry matter intake, average milk yield and growth rate of lambs were not significantly affected by the experimental additives. Blood urea concentration was significantly decreased by adding garlic oil. Results cleared that triglycerides and cholesterol concentrations were significantly decreased in G2 and G3 compared to control treatment. In conclusion, garlic oil or garlic powder supplementation to ration of lactating ewes had beneficial effects on rumen fermentation and lipids metabolism.
\end{abstract}

Keywords: Garlic powder; Garlic oil; Rumen fermentation; Milk yield; Blood parameters; Sheep

\section{Introduction}

In Egypt, sheep and goat serve as a good investment due to high fertility, low feed requirements and fast adapt to harsh environment. The productivity of sheep and goat was reported to be low due to many factors as feed shortage in quality or quantity and health constraints. Many attempts have been made for using of feed additives to increase growth rate and milk production and enhancement animal health.

One of the most important plants that were used as feed additives is Garlic (Allium sativum) plant. Lawson [1] and Afshar et al. [2] reported that garlic contains $0.3-0.6 \%$ of a volatile oil these volatile compounds are generally considered to be responsible for most of the pharmacological properties of garlic. However garlic oil is a complex mixture of many secondary plant products including Allicin (C6H10S20), diallyl sulfide (C6H10S) and allyl mercaptan (C3H6S) which makes difficult to elucidate the precise mechanism of action on rumen fermentation and its use as a feed additive.

Garlic as powder and its oil have been widely used for feeding sheep and goat to improve rumen fermentation, feed efficiency and animal health found [3-4]. While studies on the effect of using garlic as powder or oil as feed additives in

\footnotetext{
${ }^{*}$ Corresponding author

E-mail address: afafelshereef@ gmail.com
}

Copyright (C) 2017 Author(s) retain the copyright of this article. This article is published under the terms of the Creative Commons Attribution Liscense 4.0. 
reproductive performance of females animals are limit. Therefore the objective of this study was to evaluate the effects of garlic powder and garlic oil additives on voluntary feed intake, ruminal fermentation, milk yield and composition, growth of lambs and blood metabolites of female sheep.

\section{Material and methods}

This study was conducted at Maryout Research Station belongs to Desert Research Center (DRC), $35 \mathrm{~km}$ south of Alexanderia, Egypt during March to June 2016.

\subsection{Animal and ration}

Eighteen pregnant Barki sheep weighting an average $40.86 \mathrm{~kg}$ were used in this experiment starting by the last month of gestation and extend for the end of lactation period (approximately 100 days). Ewes were divided into 3 groups ( 6 in each) according to their body weights then they randomly distributed on treatments. The initial live body weights were $40.25,41.15$ and $41.17 \pm 1.48 \mathrm{~kg}$ for $1^{\text {st }}, 2^{\text {nd }}$ and $3^{\text {rd }}$ groups, respectively. The treatments included: G1 (control ration) consisted of clover hay + concentrate feed mixture (CFM) at 40:60 of dry matter bases; G2 is control ration + garlic powder (as $2 \%$ of dry matter intake) and G3 is control ration $+2 \mathrm{ml} / \mathrm{head} /$ day of garlic oil. The chemical composition of feed ingredient is shown in Table 1. Garlic powder was mixed with CFM for daily offered. Each ewe was taken garlic oil dosage individually. Feed offered was calculated to cover the maintenance and production requirements according to Kearl [5]. Voluntary feed intake was measured at 30, 60, 90 days by weighing the offered and the refusal feeds from the previous day. Fresh water was available free choice. After lambing, weight of lambs was recorded at birth then every week up to weaning age (after 3 months of parturition). For measuring daily milk yield, lambs were separated from ewes twice for 12 hours in two separated days for recording milk yield per 24 hours.

Table 1 Feed ingredient and Chemical composition (\% on DM basis) of control ration

\begin{tabular}{ll}
\hline Ingredients & $\begin{array}{l}\text { Composition } \\
\text { (\% on DM basis) }\end{array}$ \\
\hline Concentrate feed mixture & \\
Cotton seed cake & 20 \\
linseed cake & 16 \\
corn grains & 29 \\
wheat bran & 30 \\
molasses & 2 \\
premix +limestone & 2 \\
salt & 1 \\
Chemical composition \% of DM & \\
Dry matter & 91.4 \\
Organic matter & 89.6 \\
Crude protein & 16.4 \\
Crude fiber & 21.2 \\
Ether extract & 1.8 \\
Neutral detergent fiber (NDF) & 36.7 \\
Acid detergent fiber (ADF) & 21.4 \\
\hline
\end{tabular}

\subsection{Sampling and Proximate analysis}

\subsubsection{Milk samples}

Individual Milk samples taken from all animals of each group every two weeks during the experimental period (12 weeks) for analysis. Milk samples were analyzed for total solids, fat, protein and lactose using infrared spectrophotometry (Foss 120 MilkoScan, Foss Electric, Hillerød, Denmark) according to AOAC [6] procedures. 


\subsubsection{Blood samples}

At the end of lactation period blood samples were taken from 4 animals in each group. Blood samples were collected from the jugular vein at four hours after morning feeding and were directly collected into clean tubes then centrifuged at 4000 r.p.m. for 20 minutes; blood serum was then separated into a clean dried glass vial and stored at $-18^{\circ} \mathrm{C}$ for analysis. Liver function was assessed by measuring the activities of aspartate aminotransferase (AST) and alanine aminotransferase (ALT) by the method of Reitman and Frankel [7]. Kidney function was evaluated by measuring blood urea using the colorimetric methods of Fawcett and Soctt [8]. Lipid fraction in blood was assessed by measuring Triglyceride concentration [9] and Cholesterol concentration [10].

\subsubsection{Rumen samples}

Rumen liquor samples were collected from four animals within each group, four hours after feeding by a stomach tube. The rumen samples were filtered through two layers of cloth and were immediately used for the measurement of $\mathrm{pH}$ by using digital pH-meter. Strained rumen liquor was stored in glass bottles $(25 \mathrm{ml})$ with few drops of toluene and paraffin oil stored at a deep freeze $\left(-18^{\circ} \mathrm{C}\right)$ till chemical analysis. The rumen fluid samples were preserved for ammonia nitrogen (NH3-N) determination according to AOAC [6]. Total volatile fatty acids were determined according to Warner [11]. For protozoal counting, samples were preserved by adding an equal volume $(1 \mathrm{ml})$ of $18.5 \%$ formaldehyde. Then, three drops of Brilliant green dye were added to $1 \mathrm{ml}$ of this mixture, and counted as per the method described by Dehority [12].

\subsection{Statistical analysis}

Data collected was subjected to Analysis of Variance (ANOVA) using statistical analysis software (SAS) at $5 \%$ (P>0.05) level of significance [13], while the mean differences were separated using Least Significant Difference (LSD).

\section{Results and discussion}

\subsection{Rumen liquor parameters}

The effects of garlic either powder or oil additives on some rumen parameters are shown in Table 2. Data revealed that $\mathrm{pH}$ value is within the normal range, which reflect that microbial digestion of fiber and protein are optimal [14]. Either ruminal $\mathrm{pH}$ levels or VFA concentration were not significantly affected by the experimental additives. The obtained results were in harmony with the finding of Kholif et al. [4] who reported that essential oils (EO) supplementation to rations had no significant effect on ruminal $\mathrm{pH}$ of lactating goats. Similar results was obtained by Yang et al. [15] who found that the ruminal $\mathrm{pH}$ and VFA concentration were unaffected by the addition of garlic oil in lactating cow rations. While total VFA concentrations were increased for male buffalo calves fed diets supplemented with caraway (Carum carvi L.) seed powder at $2 \mathrm{~g} / \mathrm{kg}$ diet or caraway seed powder + dried garlic powder at $2 \mathrm{~g} / \mathrm{kg}$ diet each as recorded by Hassan and Abdel-Raheem [16].

Ammonia nitrogen was affected by garlic supplement and significantly decreased in groups fed garlic oil (G3) compared with the control group. These results are in agreement with those of Cardozo et al. [17] who reported that garlic oil in continuous culture reduced ammonia $\mathrm{N}$ and increased peptide amino acids nitrogen concentrations. Reduction in ammonia nitrogen concentration may be due to the essential oils modified the microbial population profile in a continuous culture experiment, reducing of Prevotella spp activity, which is mainly responsible for protein degradation and amino acids deamination as a mechanism of action of essential oils on protein metabolism [18]. Benchaar et al. [19] reported that anise, cade, capsicum, cinnamon, clove, dill, garlic, eugenol, and cinnamaldehyde and their active components in animal diets reduced amino acid deamination. They explained such reaction to a monensin-like inhibition of some hyper-ammonia producing bacteria (Clostridium sticklandii and Peptostreptococcus anaerobius). While, in some in vitro studies [20-21] amino acid deamination was not affected by EO addition in the diets. Castillejos et al. [20] found that EO addition resulted in deamination when a low protein diet rather than a high protein diet was fed. Furthermore, the high dose rates at which, deamination was evident in some studies also inhibited VFA production, which could compromise energy supply to the ruminant. In contrast, some studies have reported that EO addition increased VFA production [18, 22], whereas in other study showed no effect [24]. The results reflect that the deamination process in the rumen is depending on the nature of the diet, the dose rate and the type of EO $[21,19]$.

With regard to Protozoa number, it is clear the redaction effect on garlic as powder or oil in microbial activities. The antimicrobial properties of the aromatic plants are partially attributed to their essential oils [25, 26]. Similar results was found by Anassori et al. [27] who reported that adding garlic oil in Iranian Makoui male sheep rations reduced $(\mathrm{P}<0.05)$ protozoal population. Total volatile fatty acids, ammonia nitrogen and $\mathrm{pH}$ of rumen liquor were not affected 
by feeding of graded levels of garlic powder (80 and $120 \mathrm{~g} /$ day) along with urea treated rice straw to ruminants. However, garlic powder exhibited anti-protozoal activity since protozoa population decreased in the supplemented group [28].

In contrast, Khiaosa-ard and Zebeli [29] did not observe any specific effects of EO on microbial population, except decreased numbers when used in doses higher than $0.20 \mathrm{~g} / \mathrm{kg}$ of DM. They reported that this results mainly attributed to the hydrophobic, lipophilic nature of EO which could modulate cellular targets particularly by interacting with processes associated with the cell membrane such as ion gradients, protein translocation, phosphorylation, ATP production etc.

Table 2 Rumen liquor fermentation traits of ewes during the experimental period

\begin{tabular}{lllll}
\hline Items & G1 & G2 & G3 & $\mathbf{\pm S E}$ \\
\hline $\mathrm{pH}$ & 6.1 & 6.2 & 5.8 & 0.15 \\
TVFA`s, meq/100ml & 5.53 & 5.99 & 6.14 & 0.249 \\
NH3- N, mg/100ml & $20.8 \mathrm{a}$ & $18.7 \mathrm{ab}$ & $16.9 \mathrm{~b}$ & 0.805 \\
Protozoa x 105 (cell ml-1) & $2.67 \mathrm{a}$ & $2.34 \mathrm{ab}$ & $1.98 \mathrm{~b}$ & 0.57 \\
\hline
\end{tabular}

a,b,c Means having different superscripts within the same row differed significantly $(\mathrm{P}<0.05)$, otherwise no significant differences were detected

\subsection{Dry matter intake, milk yield and composition of ewes during the experimental period}

Dry matter intake (DMI) from either roughage or concentrate was not affected by the experimental additives compared to the control (Table 3). At early lactation period, that animals are in negative energy balance, the additional energy available due to the essential oil from medicinal supplementation is used to improve performance and reduce body reserve losses [30]. Similar results was obtained with Tager and Krause [31] who found that dry matter intake was not affected by EO supplementation in lactating dairy cow ration. The observed dry matter intake for all treatments is reflecting upon the average milk yield. It is clear that garlic either oil or powder had no significant effect on average milk yield for the all experimental groups. These fluctuated values in daily milk yield among the experimental groups may influenced by many other factors such as breed, ewes age and season of kidding, etc. this results was agreed with Tassoul and Shaver [32] who reported that adding EO (thymol, eugenol, vanillina and limonene) in high producing cows had no significant effect on milk yield.

Table 3 Dry matter intake and average milk yield of ewes during the experimental period

\begin{tabular}{lllll}
\hline Items & G1 & G2 & G3 & 土SE \\
\hline Number of animals & 6 & 6 & 6 & \\
Initial body weight, kg (last 4 weeks of gestations) & 40.25 & 40.15 & 41.17 & 1.48 \\
\hline Dry Matter Intake & & & & \\
Roughage, g/h/d & 693 & 721 & 772 & 24.7 \\
Concentrate, g/h/d & 712 & 741 & 777 & 21.3 \\
Total, g/h/d & 1405 & 1462 & 1549 & 42.9 \\
\hline Average milk yield(g/d) & & & & 47.75 \\
First month & 287.4 & 387.6 & 206.4 & 32.04 \\
Second month & 207.6 & 288 & 129.6 & 21.1 \\
Third month & 174.3 & 228 & 136.5 & 6.25 \\
Average & 223.1 & 301.2 & 157.5 & 6 \\
\hline maving different superscripts within the same row differed significantly(P<0.05), otherwise no significant differences were detected
\end{tabular}

Results of milk composition at early, mid and late lactation period are presented in Table 4. At early lactation period (first month), milk protein, lactose, total solids and solids not fat \% was significantly affected by garlic oil ration. Milk protein was increased with garlic oil as a result of improvement of ruminal microbial protein synthesis as shown in Table 2. Similar results were obtained by Spanghero et al. [33] who reported that EO increased the milk protein content. Besides, Santos et al. [34] reported that milk lactose percent was increased by EO supplementation. Milk fat \% was significant increased by garlic powder ration at mid lactation period (second month). While, at late lactation period (third month), no significant differences was found among the experimental groups in milk component \%. Yang et al. 
[15] studied the effect of garlic and juniper oils on lactating cow performance and found that the milk fat content increased with garlic oil in diet. In contrast, Benchaar et al. [19] and Tassoul and Shaver [32] reported no differences in milk composition in high producing cows when fed EO supplementation.

Table 4 Milk composition as \% of total milk yield of ewes during the experimental period

\begin{tabular}{lllll}
\hline Items & G1 & G2 & G3 & $\mathbf{\pm S E}$ \\
\hline Early lactation & & & & \\
Total solids & $9.39^{\mathrm{b}}$ & $9.30^{\mathrm{b}}$ & $10.70^{\mathrm{a}}$ & 0.23 \\
Lactose & $3.87^{\mathrm{b}}$ & $3.66^{\mathrm{b}}$ & $4,46^{\mathrm{a}}$ & 0.15 \\
Protein & $2.37^{\mathrm{b}}$ & $2.43^{\mathrm{b}}$ & $3.03^{\mathrm{a}}$ & 0.12 \\
Solid not fat & $6.46^{\mathrm{b}}$ & $6.48^{\mathrm{b}}$ & $8.34^{\mathrm{a}}$ & 0.3 \\
fat & 2.93 & 2.46 & 2.37 & 0.14 \\
\hline Mid lactation & & & & \\
Total solids & 10.37 & 10.43 & 10.03 & 0.17 \\
Lactose & 4.16 & 4 & 4.27 & 0.06 \\
Protein & 2.87 & 2.68 & 2.9 & 0.05 \\
Solid not fat & 7.74 & 7.49 & 7.98 & 0.12 \\
fat & $2.63^{\mathrm{ab}}$ & $2.95^{\mathrm{b}}$ & $2.05^{\mathrm{b}}$ & 0.16 \\
\hline Late lactation & & & & \\
Total solids & 9.07 & 9.78 & 9.35 & 0.22 \\
Lactose & 4.58 & 4.83 & 4.09 & 0.47 \\
Protein & 3.12 & 3.37 & 2.75 & 0.34 \\
Solid not fat & 6.94 & 7.59 & 7.62 & 0.21 \\
fat & 2.13 & 2.27 & 1.73 & 0.22 \\
\hline erent superscripts within the same row differed significantly(P<0.05), otherwise no significant differences were detected
\end{tabular}

\subsection{Lambs performance}

In Table 5 data cleared that birth weights of lambs was $(\mathrm{p}<0.05)$ varied among the experimental groups, their values ranged from $3.86 \mathrm{~kg}$ for control ration to $3.38 \mathrm{~kg}$ for ewes fed garlic oil additive. Birth weight of lambs is influence by different factors as year of birth, sex of the lamb, maternal litter size [35]. It was found that weaning weight tends to increase in G2, this results may be attributed to higher average milk yield for this group as shown in Table 3. Generally, data revealed that either garlic powder or garlic oil additives had positive effect on growth rate of lambs.

Table 5 Birth, weaning weight and average daily gain of lambs during growing period

\begin{tabular}{lllll}
\hline Items & G1 & G2 & G3 & $\mathbf{\pm S E}$ \\
\hline Birth weight, kg & $3.86 \mathrm{a}$ & $3.58 \mathrm{ab}$ & $3.38 \mathrm{~b}$ & 0.09 \\
Weaning weight, kg & 13.33 & 14.2 & 13.9 & 0.54 \\
Total gain, kg & 9.48 & 10.63 & 10.53 & 0.53 \\
Average daily gain, g & 105.8 & 122.3 & 121.1 & 5.83 \\
\hline
\end{tabular}

a,b,c Means having different superscripts within the same row differed significantly $(\mathrm{P}<0.05)$, otherwise no significant differences were detected

\subsection{Blood serum parameters}

The concentrations of AST are almost used for diagnosing human and domestic animal hepatic damage. While, liver enzymes such as ALT, which is a liver specific hepatocellular enzyme, released by hepatocellular damage, which used to assess liver damage [36]. Either ALT or AST were slightly lower for ewes fed G2 and G3 compared to those fed control ration (G1). These results were agreement with Kholif et al. [4] for lactating goat fed ration supplemented with E0. Blood urea concentration was significantly affected by adding garlic oil (G3). This may be due to the inhibition effect of garlic oil on deamination and lower ammonia level as shown in table 2. Results cleared that triglycerides and cholesterol concentrations were significantly decreased in G2 and G3 compared to control treatment. Numerous studies have 
demonstrated that inhibitory effect of garlic organ sulfur compounds on cholestrol biosynthesis by inhibition of HMGCoA reductase that leads to the anti-cholesterol activity of garlic [37, 2]. These results indicated the healthy effect of garlic powder and garlic oil supplementation in ewes ration.

Table 6 Blood biochemical parameters of ewes during the experimental period

\begin{tabular}{lllll}
\hline Items & G1 & G2 & G3 & $\mathbf{\pm S E}$ \\
\hline Liver function & & & & \\
AST (IU/L) & 58.5 & 57.4 & 56.05 & 0.036 \\
ALT (IU/L) & 14.07 & 12.31 & 12.18 & 0.022 \\
\hline Kidney function & & & & \\
Urea N (mmol/L) & $12.17 \mathrm{a}$ & $9.36 \mathrm{ab}$ & $8.94 \mathrm{~b}$ & 0.24 \\
\hline Lipids fraction & & & & \\
Triglycride mg/dl & $19.2 \mathrm{a}$ & $17.8 \mathrm{~b}$ & $17.00 \mathrm{~b}$ & 1.65 \\
Cholestrol mg/dl & $68.7 \mathrm{a}$ & $64.2 \mathrm{~b}$ & $63.4 \mathrm{~b}$ & 0.25
\end{tabular}

a,b,c Means having different superscripts within the same row differed significantly $(\mathrm{P}<0.05)$, otherwise no significant differences were detected

\section{Conclusion}

In conclusion, garlic oil or garlic powder supplementation to ration of lactating ewes had beneficial effects on rumen fermentation and lipids fractions in blood without any adverse effect on their lambs. Further research is needed to confirm the present results and to assess the mechanism of action of garlic additives on lipid metabolism.

\section{Compliance with ethical standards}

\section{Acknowledgments}

The authors thank the department of animal and poultry nutrition and Maryout research station for providing the enabling environment for this research work.

\section{Disclosure of conflict of interest}

This work was collaboratively carried out between all authors as follows: Author El Shereef AA designed the study and wrote the protocol. Author Nassar MS and Abo Bakr S performed the field work, data collecting and statistical analysis. Author El Shereef AA managed the literature searches, chemical analysis and writes the manuscript.

\section{Statement of ethical approval}

The experimental procedures were approved by the Animal and Poultry Production Division of DRC committee and as followed by the Veterinary and Animal Care Department.

\section{References}

[1] Lawson LD. (1996). The composition and chemistry of Garlic cloves and processed garlic. The science and therapeutic application of Allium sativum L and related species, Koch HP and Lawson (Eds). Williams and Wilkins, Boltimore, 37-108.

[2] Afshar MA, Syed AS, Hasan F, Sohrab R, Mohammad S and Mohamed T. (2012). Garlic in ruminants feeding. Asian Journal Biological Science, 1-13.

[3] Busquet MS, Calsamiglia A, Ferret MD and Kamel C. (2005). Effect of garlic oil and four of its compounds on rumen microbial fermentation. Journal Dairy Science, 88, 4393 - 4404. 
[4] Kholif SM, Morsy TA, Abdo MM, Matloup OH and Abu El-Ella AA. (2012). Effect of supplementing lactating goats rations with garlic, cinnamon or ginger oils on milk yield, milk composition and milk fatty acids profile. Journal Life Science, 4, 27-34.

[5] Kearl LC. (1982). Nutrient requirements of ruminants in developing countries. International Feedstuffs Institute, Logan, USA, 381.

[6] AOAC. (2000). Association of Official Analytical Chemists. Methods of analysis. 17th ed. Washington, DC, USA.

[7] Reitman S and Frankel S. (1957). A colorimetric method for the determination of serum glutamic oxalacetic and glutamic pyruvic transaminases. American journal of clinical pathology, 28(1), 56-63.

[8] Fawcett JK and Soctt JE. (1960). A rapid and precise method for the determination of urea. Journal of clinical pathology, 13(2), 156-159.

[9] Hatch FT and Lees RS. (1968). Practical methods for plasma lipoprotein analysis. Advances in Lipid Research, 6, 1-68.

[10] Raltiff CR and Hall F. (1973). Laborator y Manual of Clinical Biochemistry. Temple, TX, Scott and Memorial Hospital Publication Office.

[11] Warner ACI. (1964). Production of volatile fatty acids in the rumen, Method of measurement. Nutrition Abstract and Review, 34, 339.

[12] Dehority BA. (1984). Evaluation of sub-sampling and fixation procedures used for counting rumen protozoa. Applied Environment Microbiology, 48, 182-185.

[13] SAS Institute. (1985). SAS user's guide: statistics (Vol. 2). SAS Institute, Cary, NC.

[14] Firkins JL. (1996). Maximizing microbial protein synthesis in the rumen. The Journal of Nutrition, 126, 13471354.

[15] Yang WZ, Benchaar C, Ametaj BN, Chaves AV, Mc Allister TA. (2007). Effects of garlic and juniper berry essential oils on ruminal fermentation and on the site and extent of digestion in lactating cows. Journal of Dairy Science, 90, 5671-5681.

[16] Hassan EH and Abdel-Raheem SM. (2013). Response of growing buffalo calves to dietary supplementation of caraway and garlic as natural additives. World Applied Science Journal, 22, 408-414.

[17] Cardozo PW, Calsamiglia S, Ferret A, Kamel AC. (2005). Screening for the effects of natural plant extracts at different $\mathrm{pH}$ on in vitro rumen microbial fermentation of a high-concentrate diet for beef cattle. Journal of Animal Science, 83, 2572-2579.

[18] Ferme D, Banjac M, Calsamiglia S, Busquet M, Kamel C, Avgustin G. (2004). The effects of plant extracts on microbial community structure in a rumen-simulating continuous-culture system as revealed by molecular profiling. Folia Microbiol (Praha), 49, 151-155.

[19] Benchaar C, McAllister TA, Chouinard PY. (2008). Digestion, ruminal fermentation, ciliate protozoal populations, and milk production from dairy cows fed cinnamaldehyde, quebracho condensed tannin, or Yucca schidigera saponin extracts. Journal of Dairy Science, 91, 4765-4777.

[20] Castillejos L, Calsamiglia S, Ferret A and Losa AR. (2005). Effects of a specific blend of essential oil compounds and the type of diet on rumen microbial fermentation and nutrient flow from a continuous culture system. Animal Feed Science and Technology, 119, 29-41.

[21] Benchaar C, Chaves AV, Fraser GR, Wang Y, Beauchemin KA and McAllister TA. (2007). Effects of essential oils and their components on in vitro rumen microbial fermentation. Canadian Journal of Animal Science, 87, 413419.

[22] Wallace RJ. (2004). Antimicrobial properties of plant secondary metabolites Proceeding of Nutrition Society, 63, 621-629.

[23] Busquet M, Calsamiglia S, Ferret A and Kamel C. (2006). Plant extracts affect in vitro rumen microbial fermentation. Journal of Dairy Science, 89, 761-771.

[24] Newbold CJ, McIntosh FM, Williams P, Losa R, Wallace RJ. (2004). Effects of a specific blend of essential oil compounds on rumen fermentation, Animal Feed Science and Technology, 114, 105-112. 
[25] Borneman WS, Akin DE, VanEseltine WP. (1986). Effect of phenolic monomers on ruminal bacteria. Applied Environmental Microbiolgy, 52, 1331-1339.

[26] Panghal M, Kaushal V, Yadav JP. (2011). In vitro antimicrobial activity of ten medicinal plants against clinical isolates of oral cancer cases. Annals of Clinical Microbiology and Antimicrobials, 10, 21.

[27] Anassori E, Dalir-Naghadeh B, Pirmohammadi R, Taghizadeh A, Asri-Rezaei S, Maham M, Farahmand-Azar S, Farhoomand P. (2011). Garlic: a potential alternative for monensin as a rumen modifier. Livestock Science, 142, 276-287.

[28] Wanapat M, Cherdthong A, Pakdee P, Wanapat S. (2008). Manipulationof rumen ecology by dietary lemongrass (Cymbopogon citratus Stapf.) powder supplementation. Journal of Animal Science, 86, 3497.

[29] Khiaosa-ard R and Zebeli Q. (2013). Meta-analysis of the effects of essential oils and their bioactive compounds on rumen fermentation characteristics and feed efficiency in ruminants. Journal of Animal Science, 91, 18191830.

[30] Tedeschi LO, Fox DG, Tyluki TP. (2003). Potential environmental benefits of ionophores in ruminant diets. Journal of environmental quality, 32, 1591-1602.

[31] Tager LR, Krause KM. (2011). Effects of essential oils on rumen fermentation, milk production, and feeding behavior in lactating dairy cows. Journal of Dairy Science, 94, 2455-2464.

[32] Tassoul D, Shaver D. (2009). Effect of a mixture of supplemental dietary plant essential oils on performance of periparturient and early lactation dairy cows. Journal of Dairy Science, 92, 1734-1740.

[33] Spanghero M, Zanfi C, Fabbro E, Scicutella N, Camellini C. (2008). Effect of a blend of essential oils on some end products of in vitro rumen fermentation. Animal Feed Science and Technology, 145, 364-374.

[34] Santos MB, Robinson PH, Williams P, Losa R. (2010). Effects of addition of an essential oil complex to the diet of lactating dairy cows on whole tract digestion of nutrients and productive performance. Animal Feed Science and Technology, 157, 64-71.

[35] Gardner D S, Buttery P J, Daniel Z and Symonds ME. (2007). Factors affecting birth weight in sheep: Maternal environment. Journal of The society for reproduction and Fertility, 133(1): 297-307.

[36] El-Shereef AA, Helal HG, Eid EY, Abo Bakr S, El Shaer HM and Fahmy AA. (2016). Improving Kochia indica plants utilization for feeding small ruminants under saline conditions of Sinai, Egypt. International Journal of Advanced Research, 4 (7), 2217-2224.

[37] Cho SB and Xu S. (2000). Effects of allyl mercaptan and various allium-derived compounds on cholesterol synthesis and secretion in Hep-G2 cells. Comp. Biochemical Physiology, C: Pharmacol. Toxicol. Endocrinol., 126, 195-201.

\section{How to cite this article}

Nassar M, El Shereef A and Abo BS. (2017). Influence of feeding garlic plant either as powder or oil on reproductive performance of ewes. GSC Biological and Pharmaceutical Sciences, 1(3), 59-66. 